\title{
Pelatihan Perancangan Aplikasi Perhitungan Harga Pokok Dengan Microsoft Excel Bagi Anggota Dharma Wanita Bappeda Kota Mataram
}

\author{
Nina Karina Karim*, Siti Atikah, Yusli Mariadi, Indria Puspitasari Lenap \\ Fakultas Ekonomi dan Bisnis, Universitas Mataram, Mataram, Indonesia
}

\section{Article history}

Received: 30-12-2020

Revised: 14-03-2021

Accepted: 16-06-2021

*Corresponding Author:

Nina Karina Karim,

Fakultas Ekonomi dan Bisnis,

Universitas Mataram,

Mataram, Indonesia;

Email:

ninakarim@unram.ac.id.
Abstract: Knowledge of business planning will help household businesses increase family income which in turn will make it easier to achieve common goals such as planning children's education, preparing pension funds, preparing pilgrimage funds and various other family needs. Some members of the Dharma Wanita Unit Bappeda Mataram City run household businesses such as food catering, handicrafts and buying and selling businesses. Not only planning the use of available financial resources in household businesses, this training aims to provide knowledge and ideas for members of the Dharma Wanita Unit Bappeda Mataram City regarding ways that can be applied to family businesses in calculating the cost of production of household businesses and increase family income through more appropriate business financial planning. By using simple functions in the Microsoft Excel program, service activity participants are trained to design simple applications that can be used to calculate the cost of production of household goods such as handicrafts, catering services and even retail.

Keywords: application; Microsoft Excel; financial planning; costing

Abtrak: Pengetahuan mengenai perencanaan usaha akan membantu usaha rumah tangga dalam meningkatkan penghasilan keluarga yang pada gilirannya akan mempermudah untuk mencapai tujuan bersama seperti merencanakan pendidikan anak, menyiapkan dana pensiun, menyiapkan dana ibadah haji dan berbagai kebutuhan keluarga lainnya. Anggota Dharma Wanita Unit Bappeda Kota Mataram beberapanya menjalankan usaha rumah tangga seperti catering makanan, kerajinan tangan dan usaha jual-beli. Tidak hanya merencanakan penggunaan sumber daya keuangan yang tersedia dalam usaha rumah tangga saja, pelatihan ini bertujuan untuk memberikan pengetahuan dan gagasan bagi anggota Dharma Wanita Unit Bappeda Kota Mataram mengenai cara-cara yang dapat diterapkan bagi usaha keluarga dalam menghitung harga pokok produksi usaha rumah tangga dan meningkatkan pendapatan keluarga melalui perencanaan keuangan usaha yang lebih tepat. Dengan menggunakan fungsi-fungsi yang sederhana pada program Microsoft Excel, peserta kegiatan pengabdian dilatih untuk merancang aplikasi sederhana yang bisa digunakan untuk menghitung harga pokok produksi barang hasil usaha rumah tangga seperti kerajinan, jasa boga bahkan ritel.

Kata Kunci: aplikasi; Microsoft Excel; perencanaan keuangan; penetapan harga pokok 


\section{PENDAHULUAN}

Perencanaan dibutuhkan untuk mempermudah dalam mencapai tujuan apa pun. Otoritas Jasa Keuangan (OJK), melalui berbagai upaya, berusaha menggalakkan masyarakat untuk melakukan perencanaan keuangan, terutama dalam keluarga (Karim, 2019). Dengan memiliki perencanaan, kegiatan yang dilakukan keluarga akan lebih terarah. Setiap keluarga memiliki tujuan yang relatif umum seperti perencanaan pendidikan anak, perencanaan biaya kesehatan, perencanaan pensiun, perencanaan liburan dan perencanaan biaya untuk beribadah seperti melakukan ibadah haji. Tanpa adanya perencanaan keuangan, sumber daya yang dimiliki keluarga, misalnya dalam hal ini gaji atau harta warisan bisa salah alokasi bahkan kehabisan sebelum tujuan tercapai. Dengan adanya perencanaan keuangan, kita dapat mengetahui seberapa banyak harta yang kita miliki, untuk apa saja harta tersebut digunakan, apakah kita perlu mencari sumber penghasilan lain atau bagaimana kita bisa memanfaatkan harta yang berlebih.

Merencanakan keuangan sebenarnya bukan merupakan hal yang baru, akan tetapi selama ini perencanaan keuangan diidentikkan dengan menabung. Kegiatan menabung dilakukan sebagai upaya penghematan harta yang dimiliki seseorang. Akan tetapi, dengan kondisi tingkat bunga tabungan saat ini, uang yang kita simpan di bank akan tergerus oleh jumlah biaya administrasi bulanan yang dikenakan bank untuk simpanan di rekening bank. Alih-alih uang yang kita harapkan bisa dihemat malah akan berkurang jika kenaikan jumlahnya tidak bisa menutupi besaran biaya administrasi bulanan yang dikenakan bank. Dengan kondisi tersebut, opsi apa yang bisa kita ambil jika kita ingin merencanakan keuangan dengan mengelola uang yang kita miliki?

Industri atau usaha rumah tangga adalah salah satu bentuk upaya keluarga untuk menambah penghasilan keluarga. Sampai dengan tahun 2016, BPS kota Mataram mencatat adanya 1.831 unit usaha industri non-formal yang mempekerjakan 7.192 orang (mataramkota.bps.go.id). Industri rumah tangga menjadi solusi untuk membantu menyerap tenaga kerja dan menggerakkan perekonomian di lini paling dasar yaitu keluarga. Dengan menyediakan modal semampunya, suatu keluarga bisa memulai usaha seperti binatu, catering, produksi kerajinan tangan, produksi makanan cemilan bahkan pengolahan sampah plastik.

Salah satu kunci penting dalam menciptakan laba suatu usaha adalah proses penetapan harga yang didasari oleh penghitungan harga pokok produk secara tepat. Penghitungan harga pokok merupakan salah satu bagian perencanaan sumber daya usaha. Dengan mengetahui komponen apa saja yang harus diperhitungkan untuk menghasilkan suatu produk mulai dari pemilihan bahan mentah hingga menjadi barang yang siap dijual, penghitungan harga pokok bisa menjadi acuan untuk merencanakan, menghitung bahkan memperkirakan keuntungan yang bisa dihasilkan suatu usaha.

Kebanyakan usaha rumah tangga menetapkan harga barang atau jasa yang dijualnya hanya berdasarkan perbandingan dengan produk yang serupa bahkan hanya dengan perkiraan. Karena cara menetapkan harga yang tidak didasari penghitungan harga pokok yang sesuai, maka keuntungan usaha yang awalnya dirasa banyak, pada gilirannya akan tidak berarti ketika timbul biaya yang ternyata terkait dengan produksi yang semestinya diperhitungkan pada saat menetapkan harga jual. Biaya-biaya tersebut antara lain biaya bahan pembantu, biaya tenaga kerja pembantu, biaya pemeliharaan alat pendukung dan bentuk biaya pabrikasi atau overhead lainnya.

Penggunaan komputer dan gawai pintar sudah bukan menjadi hal yang asing dalam mendukung kegiatan sehari-hari. Program Microsoft Excel yang merupakan bagian dari Microsoft Office yang sudah terprogram di hampir semua perangkat komputer dan gawai pintar akan digunakan untuk merancang aplikasi sederhana yang bisa difungsikan untuk menghitung harga pokok produk hasil usaha rumah tangga. Oleh karena itu, tim pengabdian berinisiatif untuk mendorong masyarakat untuk memanfaatkan program yang sudah ada dalam genggaman kita sehari-hari agar dapat 
menghasilkan informasi yang berguna untuk mendukung usaha rumah tangga. Mengingat hampir seluruh lapisan masyarakat sudah cukup terbiasa dengan gawai pintar, tidak begitu sulit bagi para peserta yang menjadi target kegiatan pengabdian ini untuk menggunakan program Microsoft Excel yang antar mukanya cukup interaktif dan mudah dipahami.

Microsoft Excel sebagai salah satu program dasar yang terdapat dalam Microsoft Office yang sudah terprogram di hampir semua perangkat elektronik seperti telepon seluler, tablet dan mikrokomputer (laptop), dapat menjadi program yang bisa dimanfaatkan untuk mendukung kegiatan harian. Program pembuatan spreadsheet tersebut selain digunakan untuk mencatat data dalam bentuk tabel-tabel yang bisa menjalankan hitungan sederhana, bisa digunakan untuk merancang aplikasi sederhana untuk menghitung harga pokok produk. Banyak pengguna gawai pintar dan komputer yang selama ini menganggap bahwa program seperti Microsoft Excel ini sulit dipelajari atau malah sebaliknya, bagi yang telah menggunakannya sebagai penghasil spreadsheet, belum mengetahui fungsi pemrograman yang bisa dilakukan dengan perintah-perintah sederhana yang sudah tersedia dalam program tersebut. Melalui pelatihan ini, peserta pelatihan akan dibekali pengetahuan dasar untuk merancang aplikasi yang dapat digunakan untuk menghitung harga pokok produk dengan menggunakan Microsoft Excel kemudian mengakses aplikasi yang telah dirancang dengan gawai pintar seperti telepon seluler dan tablet.

Anggota Dharma Wanita Unit Bappeda Kota Mataram yang pendidikan dasarnya mulai dari tamatan SMA hingga S2 dianggap cukup mumpuni untuk menerima materi pelatihan ini. Selain itu, bekal pengetahuan mengenai penghitungan harga pokok produk ini bisa dimanfaatkan untuk mendukung usaha rumah tangga yang mereka jalani agar dapat lebih tepat merencanakan sumber daya dan penghasilan keluarga. Untuk itu, perlu dilakukan pelatihan perancangan aplikasi penghitungan harga pokok dengan Microsoft Excel, disertai dengan praktek penggunaannya.

\section{METODE}

Metode dan pendekatan yang digunakan untuk mencapai kompetensi pelatihan dan perancangan adalah metode partisipatif berbasis teknologi informasi dengan pendekatan andragogi. Pendekatan ini merupakan pendekatan pembelajaran untuk orang dewasa. Komponen pembelajaran ini mencakup dua hal yaitu penyampaian materi secara searah (pemaparan dan tutorial) sebesar 50\% dan sesi praktik sebesar 50\%. Akan tetapi, dengan terjadinya pandemi COVID-19, kegiatan pelatihan dialihkan dalam bentuk online tutorial melalui grup di media sosial di mana setiap peserta mendapat kesempatan untuk bertanya mengenai materi yang diberikan melalui video dan presentasi di grup Whatsapp.

\section{HASIL DAN PEMBAHASAN}

Pelaksanaan kegiatan pengabdian ini dilakukan dengan metode pemaparan, tutorial dan diskusi. Pada tahap pemaparan, peserta diberikan pengetahuan dan pemahaman melalui presentasi oleh pemateri serta motivasi agar memiliki kemauan merancang aplikasi penghitungan harga pokok dalam bentuk presentasi Powerpoint dan video tutorial. Kemudian peserta diberikan modul yang berisi fungsi-fungsi sederhana pada Microsoft Excel dan langkah-langkah perancangan aplikasi. Pada sesi praktik, peserta mempraktikkan langkah-langkah perancangan aplikasi yang telah dipelajari dan menyesuaikan rancangan dengan kebutuhan informasi yang disesuaikan dengan usaha rumah tangga masing-masing secara mandiri. Selanjutnya, peserta diberikan kesempatan untuk mendiskusikan masalah yang dihadapi berkaitan dengan kesulitan dalam aspek pengoperasian aplikasi dan hal-hal 
yang perlu dipertimbangkan dalam menghitung harga pokok produk yang sesuai dengan usaha rumah tangga tertentu melalui grup Whatsapp.

Sejak mewabahnya COVID-19 di pulau Lombok yang mengakibatkan pengaturan berbagai kegiatan yang mengumpulkan orang di tempat umum serta pembatasan jarak, kegiatan pengabdian terpaksa disesuaikan dengan kondisi agar tidak membayahakan kesehatan tim pengabdian dan peserta pelatihan. Setelah mengkoordinasikan rencana pelaksanaan pengabdian dengan pimpinan Dharma Wanita Kota Mataram, ditemukan berbagai kesulitan untuk mengadakan pertemuan baik secara luring maupun daring, antara lain penetuan waktu pelaksanaan kegiatan pengabdian yang tidak berbenturan dengan tugas kantor maupun kewajiban ibu-ibu untuk mendampingi anak-anak mereka dalam melaksanakan pembelajaran jarak jauh di rumah masing-masing. Oleh sebab itu, pelaksanaan pelatihan dilakukan melalui media sosial Whatsapp. Anggota Dharma Wanita Bappeda Kota Mataram tergabung dalam grup media sosial Whatsapp sehingga pemberian materi pelatihan mengenai perancangan aplikasi penghitungan harga pokok dilakukan melalui media tersebut. Materi pelatihan berupa video dan fail presentasi yang dibagikan melalui grup Whatsapp Dharma Wanita Bappeda Kota Mataram. Selain itu, pendampingan intensif diberikan kepada anggota secara individu baik melalui Whatsapp maupun dengan Zoom. Materi yang bersifat visual membantu kesuksesan penyampaian materi mengenai perancangan aplikasi sederhana untuk menghitung harga pokok dengan menggunakan Microsoft Excel menjadi lebih mudah diterima bahkan menarik minat peserta kegiatan.

Kegiatan ini difasilitasi oleh empat orang tim pengabdian sebagai pemberi materi dan tutor daring bagi kegiatan perancangan aplikasi sederhana untuk menghitung harga pokok dengan menggunakan Microsoft Excel, serta 25 peserta yang terdiri dari anggota Dharma Wanita serta staf Kantor Bappeda Kota Mataram.

Materi pelatihan diberikan melalui metode tutorial dan diskusi aktif melalui media sosial dan aplikasi pertemuan daring di mana peserta terlibat langsung dalam kegiatan brainstorming mengenai opsi-opsi yang dapat diterapkan untuk memperhitungan komponen-komponen biaya yang harus diperhitungan untuk berbagai usaha rumah tangga yang berbeda. Materi pelatihan disajikan melalui gambar-gambar presentasi dan video agar dapat lebih mudah dipahami dan menarik perhatian peserta.

Setelah materi pelatihan diberikan, perserta diberikan kesempatan untuk mencoba mempraktekkan pengetahuan yang mereka terima dengan menggunakan aplikasi yang telah dirancang. Selain itu, peserta juga diberi kesempatan untuk menggunakan aplikasi tersebut dalam mengubah data dan fungsi dalam aplikasi yang telah dirancang dan bisa diakses dengan menggunakan perangkat telepon seluler.

Sesi terakhir dari rangkaian kegiatan ini adalah proses diskusi dan tanya jawab yang mencakup rangkaian keseluruhan dari aktivitas pelatihan. Peserta mengemukakan kesulitan yang dihadapi dalam proses tersebut kepada pemateri dan dilakukan penilaian atas hasil kerja tersebut, kemudian jika masih ada yang kurang diberikan arahan serta saran perbaikan. Selain itu, masingmasing peserta diberi kesempatan untuk mengkomunikasikan hasil kerjanya dengan peserta yang lain sehingga satu dengan yang lain dapat saling berbagi ilmu melalui grup Whatsapp.

\section{KESIMPULAN DAN SARAN}

\section{Kesimpulan}

Kegiatan pengabdian kepada masayarakat tahun 2020 ini telah berhasil dilaksanakan walaupun banyak hambatan akibat adanya pandemi COVID-19. Materi mengenai perancangan aplikasi penghitung harga pokok dengan Microsoft Excel diterima dengan baik oleh perserta walau hanya disampaikan melalui media sosial. Tanggapan peserta pelatihan mengenai kegiatan yang dilaksanakan menunjukkan bahwa peserta berharap bahwa kegiatan pengabdian yang memberi 
tambahan pengetahuan dan keterampilan semacam ini perlu dilanjutkan. Tanggapan positif dan antusiasme peserta tersebut menjadi indikator bahwa tujuan kegiatan pengabdian ini telah tercapai.

\section{Saran}

Beberapa hal yang perlu menjadi bahan rekomendasi untuk dapat diterapkan dalam melaksanakan pelatihan perancangan aplikasi sederhana untuk menghitung harga pokok dengan menggunakan Microsoft Excel:

1. Perlu dilakukan kegiatan pengabdian lanjutan tentang penggunaan fungsi-fungsi dalam Microsoft Excel agar bisa memaksimalkan pengembangan aplikasi yang telah dirancang sesuai dengan kondisi usaha masing-masing.

2. Melakukan komunikasi rutin selama kurang lebih satu atau dua bulan antara pemateri dengan peserta baik dengan langsung bertatap muka atau melalui media lain seperti telepon dan media sosial untuk memastikan bahwa para peserta benar-benar mampu menerapkan materi yang didapat selama kegiatan pelatihan.

\section{Ucapan Terima Kasih}

Keberhasilan pelaksanaan kegiatan ini tidak terlepas dari partisipasi, dukungan dan bantuan moral, finansial maupun fisik dari banyak pihak. Oleh karena itu, kami mengucapkan ucapan terima kasih kepada Dekan Fakultas Ekonomi dan Bisnis Universitas Mataram, Bapak Dr. Muaidy Yasin, MS; Kepala Bappeda Kota Mataram, Bapak Ir. H. Amiruddin, M.Si.; Ketua Dharma Wanita Unit Bappeda Kota Mataram, Ibu Hj. Baiq Lily C. Amiruddin, SH; dan terlebih lagi kepada peserta kegiatan.

\section{DAFTAR PUSTAKA}

Karim, Nina Karina, Siti Atikah, Indria Puspitasari Lenap, 2019. Pelatihan Perencanaan Keuangan dan Pasar Modal Bagi Staf dan Anggota Dharma Wanita Lingkup Bappeda Kota Mataram, Laporan Pengabdian PNBP, Universitas Mataram.

Laudon, Kenneth C. dan Jane P. Laudon, 2013. Management Information Systems 12th Edition, Pearson Horizon Editions, Pearson.

McLeod, Raymond dan George Schell, 2007. Management Information Systems 10th Edition, Pearson Education International, Prentice Hall.

Reeve, James M., Carl S. Warren, dan Jonathan E. Duchac, 2010. Accounting Principles Using Excel for Success 2nd Edition, International Edition, South-Western Cengage Learning.Otoritas Jasa Keuangan, Perencanaan Keuangan. 